\title{
GFAPa IgG-associated encephalitis upon daclizumab treatment of MS
}

Felix Luessi, MD,* Sinah Engel,* Annette Spreer, MD, Stefan Bittner, MD, and Frauke Zipp, MD

Neurol Neuroimmunol Neuroinflamm 2018;5:e481. doi:10.1212/NXI.0000000000000481
Correspondence

Dr. Luessi

luessi@uni-mainz.de

\begin{abstract}
\section{Objective}

To describe a case of glial fibrillary acidic protein (GFAP) $\alpha$ immunoglobulin G (IgG)associated encephalitis in a patient referred to us with MS on daclizumab treatment and to summarize characteristics of 5 additional recent German MS cases of serious encephalitis along with a previously published American case of CNS vasculitis associated with daclizumab.
\end{abstract}

\section{Methods}

Evaluation of cause, clinical symptoms, and treatment response.

\section{Results}

The 6 patients included 4 women and 2 men. The median age at onset was 38 years (range 32-51 years). Clinical presentation was marked by progressing neuropsychologic and/or neurologic deficits. Additional drug rash with eosinophilia was seen in 3 patients, whereas 2 patients showed a highly active demyelinating process. Examination of CSF samples detected pleocytosis, elevated total protein levels, and GFAP $\alpha$ IgG antibodies, which were not found in serum. In our case, we discovered autoimmune GFAP astrocytopathy associated with encephalitis as secondary autoimmunity, which was steroid responsive. Clinical outcome of other cases was marked by partial recovery in 4 patients and persistent foster care in 1 patient.

\section{Conclusions}

Our case of GFAPa IgG-associated encephalitis along with 12 other cases of serious inflammatory brain disorders following daclizumab treatment so far indicates that interfering with NK cells and Tregs by anti-CD25 antibody therapy can result in severe secondary CNS autoimmunity in man.

*These authors contributed equally to this work.

From the Department of Neurology and Focus Program Translational Neuroscience (FTN), Rhine Main Neuroscience Network (rmn2), University Medical Center of the Johannes Gutenberg University Mainz, Germany.

Funding information and disclosures are provided at the end of the article. Full disclosure form information provided by the authors is available with the full text of this article at Neurology.org/NN.

The Article Processing Charge was funded by the authors.

Ethical standards: All procedures performed in this case report were in accordance with the ethical standards of the institutional and/or national research committee and with the 1964 Helsinki declaration and its later amendment or comparable ethical standards.

Informed consent: The patient was informed of the intent to publish the case report and gave his written consent.

This is an open access article distributed under the terms of the Creative Commons Attribution-NonCommercial-NoDerivatives License 4.0 (CC BY-NC-ND), which permits downloading and sharing the work provided it is properly cited. The work cannot be changed in any way or used commercially without permission from the journal. 


\section{Glossary}

EMA = European Medicines Agency; FDG = 18F-Fluorodeoxyglucose; FLAIR = fluid attenuation inversion recovery; GFAP = glial fibrillary acidic protein; IgA = immunoglobulin A; IgG = immunoglobulin G; IL-2 = interleukin 2; NK = natural killer; NMO = neuromyelitis optica; $\mathbf{M R}=$ magnetic resonance; RRMS = relapsing-remitting MS; $\mathbf{T h}=$ thoracic vertebra; $\mathbf{W B C}=$ white blood cell.

The antibody daclizumab (Zinbryta; Biogen, Cambridge, MA) inhibits the interleukin 2 (IL-2) signaling pathway by blocking the IL-2 receptor $a$ (CD25). In clinical trials, daclizumab had proven to be an effective therapy for patients with relapsing-remitting MS (RRMS). ${ }^{1}$ However, recently, the use of daclizumab in MS was overshadowed by safety concerns associated with secondary autoimmunity. We here report the occurrence of steroid-responsive glial fibrillary acidic protein (GFAP)-mediated encephalitis in a patient with MS receiving daclizumab together with a series of other severe autoimmune CNS adverse events.

\section{Case report}

We describe a 32-year-old Caucasian man with the first onset of RRMS in 2013 presenting with sensory spinal syndrome below thoracic vertebra (Th) 7. MRI scans showed disseminated cerebral and spinal lesions including 2 asymptomatic contrast-enhancing left parietal lesions. Analysis of CSF showed pleocytosis with 14 white blood cells (WBCs)/ $\mu \mathrm{L}$ (100\% mononuclear cells) and the presence of oligoclonal bands. Differential diagnoses were tested for and thus ruled out. The diagnosis of RRMS was therefore made according to McDonald Criteria 2010. Treatment with interferon $\beta$-1a (Avonex; Biogen, Cambridge, MA) was initiated. Because of clinical and paraclinical disease activity, therapy was escalated to dimethyl fumarate (Tecfidera; Biogen, Cambridge, MA) in September 2016 (figure 1A). Because of gastrointestinal side effects under dimethyl fumarate, daclizumab therapy was started in December 2016. The recommended blood examinations were uneventful.

In August 2017, the patient demonstrated aggressive behavior and occasionally expressed suicidal thoughts. Because of fluctuating dysarthria, progressive memory loss, fatigue, and depression, the patient was admitted to our hospital in December 2017. On initial examination, the patient was afebrile and demonstrated perceptive impairment, confusion, incoherent thoughts, and delusions. Neurologic examination revealed ataxia and nystagmus. His blood tests and differential blood count were normal. Lymphocyte subset analysis revealed values within the range of untreated patients with RRMS. ${ }^{2}$ The MRI scan showed a new juxtacortical right frontal lesion and a new focal gliosis at Th $3 / 4$ (figure 1B), both without contrast enhancement. Electroencephalography showed moderately severe encephalopathy with generalized theta activity. A lumbar puncture revealed $74 \mathrm{WBC} / \mu \mathrm{L}$ (100\% mononuclear cells), a CSF protein level of $61.5 \mathrm{mg} / \mathrm{dL}$, and a CSF lactate level of 2.7 $\mathrm{mmol} / \mathrm{L}$. Oligoclonal bands and intrathecal immunoglobulin A (IgA) synthesis were present (figure 2A). Diagnostic tests (detailed in Supplement, links.lww.com/NXI/A60) did not disclose any infectious agent. Immunostaining of rat hippocampal tissue exhibited GFAP immunoglobulin G (IgG) antibodies in CSF (figure 2B, diagnostic laboratory of Euroimmun AG; Lübeck, Germany). GFAP antibodies could not be detected in serum (figure 2C). Antigen specificity was further confirmed by GFAP $\alpha$-transfected HEK293 cell-based assay. Patient GFAP-IgGs reacted with GFAPa isoform (figure 2D), whereas no reaction was observed on control-transfected cells (figure $2 \mathrm{E}$ ).

Magnetic resonance (MR) angiography did not show vascular abnormalities, but it demonstrated a slight brain edema as volume increase in comparison to pre-MRI from 2016 (figure 1B). An additional 18F-Fluorodeoxyglucose (FDG)-PET scan revealed no evidence of tumors. Chest CT findings were normal.

With a diagnosis of autoimmune GFAP $\alpha$ astrocytopathy, we started treatment with $1,000 \mathrm{mg}$ methylprednisolone/d, followed by 5 courses of plasma exchange every other day. The patient gradually improved while methylprednisolone was continued with $100 \mathrm{mg} / \mathrm{d}$ orally and tapered over time. Neuropsychologic examination thereafter demonstrated ongoing impairment in all cognitive domains including attention span, attention selectivity, information processing, short-term memory, verbal and figural long-term memory, and executive functions. However, there were no incoherent thoughts or noticeable behavioral disturbances, no signs of depression, and no ataxia.

Despite the clinical improvement, the follow-up MRI in March 2018 showed, apart from a reduction in swelling, progressive non-contrast-enhancing white matter lesions with a prominent radial pattern, which resembles a previously published patient with GFAP meningoencephalitis. ${ }^{3}$ Followup CSF analysis revealed $39 \mathrm{WBC} / \mu \mathrm{L}$, persistent intrathecal synthesis of IgA, but normal CSF protein and lactate levels.

In the context of MRI results and persistent CSF pleocytosis under continuous steroid therapy, treatment with rituximab (MabThera; Roche, Basel, BS) was added. This led to a stabilization of the clinical status. Although neuropsychologic testing in general still showed significant deficits, the performance in some cognitive domains had improved. Currently, 

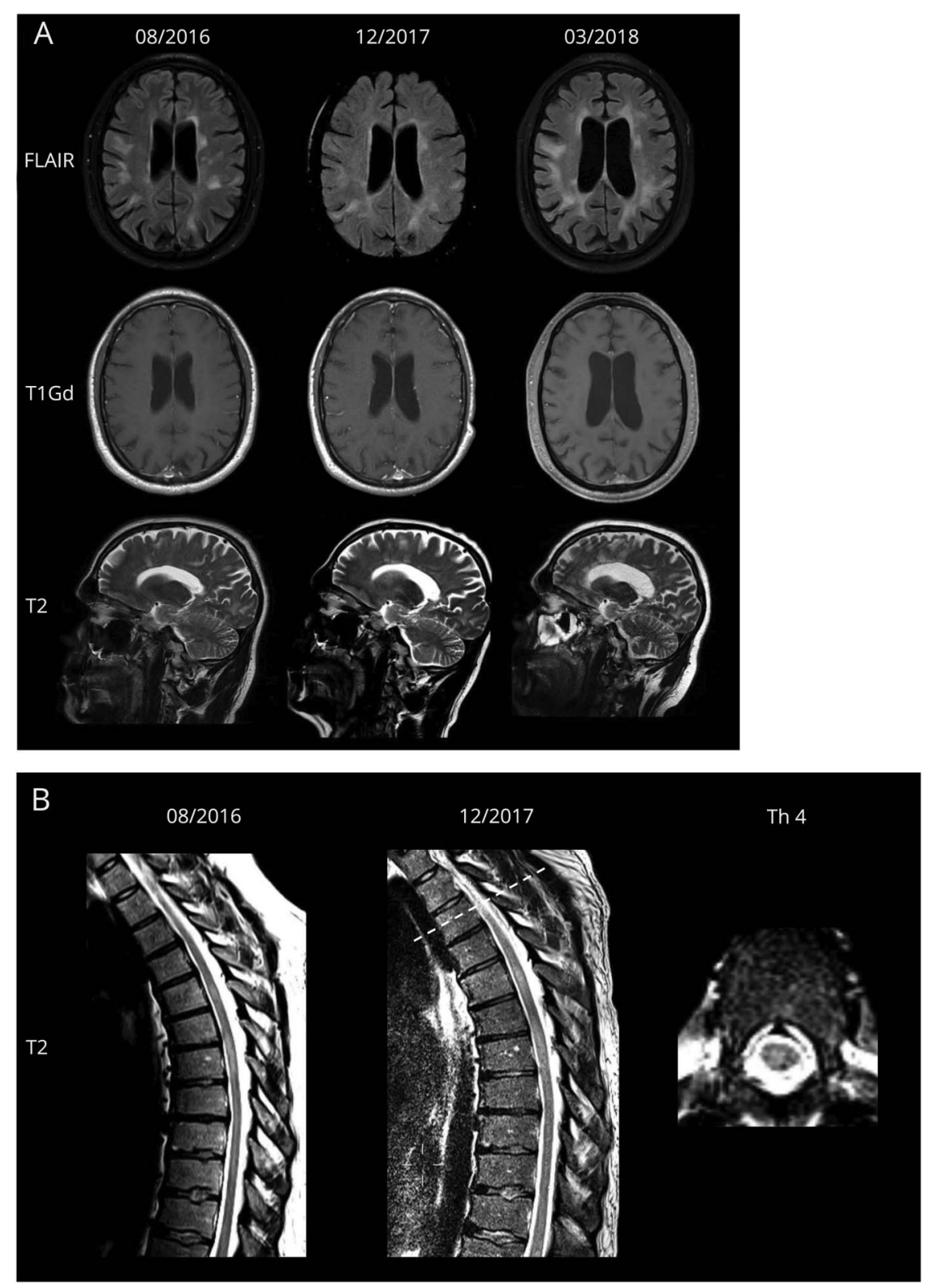

(A) Upper row: FLAIR axial images show progressive white matter lesions without contrast enhancement and distinct cerebral atrophy. Middle row: T1Gd-weighted images show no gadolinium enhancement. Lower row: T2weighted sagittal images. A prominent radial pattern within T2-weighted axial pictures resembles a previously published patient with glial fibrillary acidic protein meningoencephalitis with a radial pattern of periventricular gadolinium enhancement. (B) T2-weighted sagittal images before daclizumab therapy and during encephalitic illness. T2-weighted axial image shows new focal gliosis at Th 3/4. FLAIR = fluid attenuated inversion recovery; $\mathrm{Gd}$ = gadolinium; $\mathrm{Th}=$ thoracic vertebra. the patient is capable of participating in daily life activities again. Anonymized data will be shared on request from any qualified investigator.

\section{Discussion}

This report of a patient with encephalitis extends the spectrum of secondary autoimmune complications of daclizumab treatment by GFAP autoimmunity. ${ }^{3,4}$ GFAP-IgG autoantibodies are rarely found in CSF in healthy controls or patients with other diseases. A recent study using GFAPa isoformtransfected cells reported GFAP antibodies in 0 of 20 CSF specimens of MS patients. ${ }^{3}$ When detected in CSF, GFAP-IgG autoantibodies have been identified as a biomarker for a distinct spectrum of immunotherapy-responsive autoimmune CNS disorders. ${ }^{5}$ Anti-GFAP-IgG may occur alone or in the setting of other diagnoses, for example, anti-NMDA-receptor encephalitis or CNS vasculitis. Because one-third of cases with GFAP-IgG are paraneoplastic, neoplasia was ruled out in our case by FDG-PET. Because MS is ultimately a diagnosis of exclusion, there is a slight possibility that the primary pathology in this patient was a neuroinflammatory disorder other than MS. However, taking into account the relapsing-remitting disease course, the appearance of lesions typical in MS, the CSF findings in 2012, and the absence of anti-GFAP autoantibodies in $\mathrm{MS} \mathrm{CSF}^{3}$ it is most likely that the induction of GFAP autoimmunity is causally linked to daclizumab treatment. A limitation of our report is the lack of GFAP antibody investigation before deterioration on daclizumab treatment. 

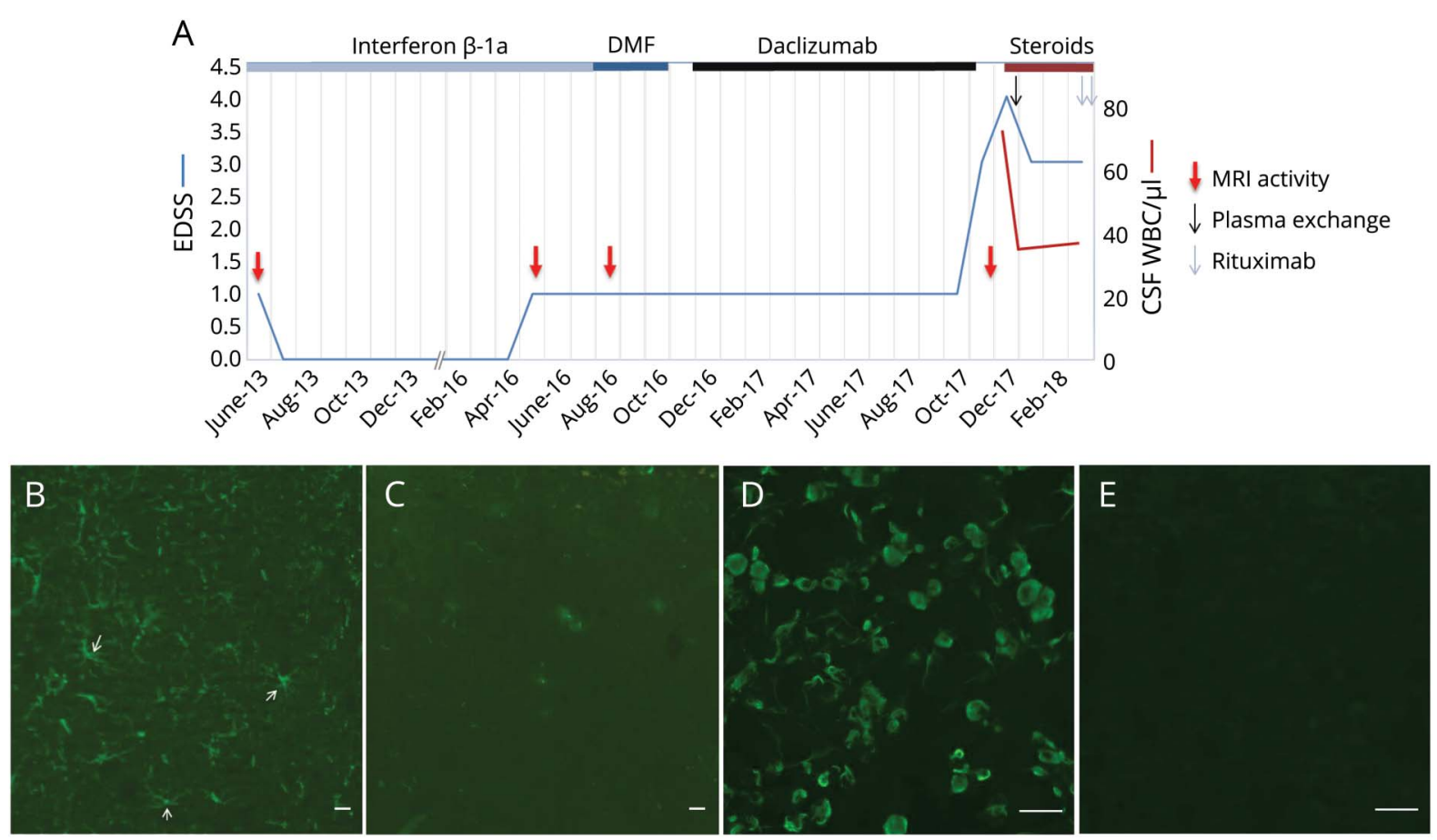

(A) Disability assessed by the EDSS is displayed as a blue line. Clinical relapses and MRI activity (red arrows) are indicated. Duration of immunomodulatory treatments is depicted with lines of different colors on the top of the diagram. (B) Distribution of patient CSF IgG (green) in the rat hippocampus parenchyma is consistent with astrocytes (arrows). (C) Absence of specific patient serum IgG binding (diluted 1:100, green) in the brain parenchyma. (D) Antigen specificity of CSF IgG was further confirmed by glial fibrillary acidic protein a-transfected HEK293 cell-based assay CBA. (E) Absence of CSF IgG binding on control-transfected cells. Scale bars: 20 m (B-E). DMF = dimethyl fumarate; EDSS = Expanded Disability Status Scale; Ig = immunoglobulin G; $\mathrm{WBC}=$ white blood cell.

Meanwhile, the European Medicines Agency (EMA) has received notifications of 12 other patients having severe encephalopathy syndromes following daclizumab therapy, 4 of those with fatal outcome. Among 5 German cases, 3 were suspected of drug rash with eosinophilia and systemic symptoms syndrome with CNS manifestation and 2 with highly active demyelinating process (data retrieved from Paul Ehrlich Institute, Federal Institute for Vaccines and Biomedicines, Germany). One American patient had CNS vasculitis ${ }^{6}$ (table).

Underlying mechanisms like inhibition of Tregs without concomitant expansion of immunoregulatory CD $56^{\text {bright }}$ natural killer (NK) cells ${ }^{6}$ or general immune suppression by depletion of activated effector $\mathrm{CD} 25^{+} \mathrm{T}$ cells on daclizumab can currently merely be speculated. Autoimmune encephalitis in our patient may have been induced by GFAP-IgG in combination with enhancement of NK cells on daclizumab therapy, eventually resulting in antibody-dependent cellular cytotoxicity. Such a mechanism has previously been described for neuromyelitis optica (NMO) lesions. ${ }^{7}$

Cases of suspected secondary autoimmunity under daclizumab treatment have been previously reported including 2 deaths of study patients. In both cases (autoimmune hepatitis and psoas abscess), daclizumab treatment could not be excluded as a contributing factor. ${ }^{8,9}$ In 2017, the indication of the drug had to be restricted because of another death by liver injury that was most likely caused by autoimmune hepatitis. ${ }^{10}$ Moreover, the rare occurrence of autoimmune hemolytic anemia under daclizumab treatment has been reported in an extension study. ${ }^{10}$ After the recent EMA decision to urgently review daclizumab, in March 2018, marketing authorizations of daclizumab were withdrawn following twelve cases of serious inflammatory brain disorders, 4 of them with fatal outcome. In the 13th patient, who was referred to us, we discovered antiGFAP encephalitis, which was steroid responsive.

It has to be assumed that in man, disturbing the NK cell/Treg balance appears to be detrimental, even if the upregulated NK cells are considered as regulatory.

\section{Author contributions}

F. Luessi and S. Engel: study concept and design, acquisition of data, and analysis and interpretation. A. Spreer: analysis and interpretation and critical revision of the manuscript for important intellectual content. S. Bittner and F. Zipp : critical revision of the manuscript for important intellectual content.

\section{Acknowledgment}

The authors thank Cheryl Ernest for proofreading and editing the manuscript. This study has been supported by the German Research Foundation (DFG, CRC-TR-128 to F.Z.). 
Table Demographic, clinical, imaging, CSF, and histologic findings in 6 German cases for which details are available to us and 1 American case of serious inflammatory brain disorders

\begin{tabular}{|c|c|c|c|c|c|c|c|c|}
\hline & $\begin{array}{l}\text { Sex/Age } \\
\text { at onset } \\
\text { (y) }\end{array}$ & Diagnosis & Presenting symptoms & MRI findings & CSF & Histologic findings & Therapy & Outcome \\
\hline 1 & $\begin{array}{l}\text { M/51/ } \\
\text { Germany }\end{array}$ & $\begin{array}{l}\text { Highly active MS disease } \\
\text { and ADEM }\end{array}$ & $\begin{array}{l}\text { Severe dysphagia, } \\
\text { dysarthria, increased } \\
\text { fatigue, paresis of the right } \\
\text { leg, and vigilance reduction }\end{array}$ & $\begin{array}{l}\text { Multiple }(>50) \text { contrast-enhancing lesions } \\
\text { with perifocal edema, significant increase } \\
\text { in lesion load with development of central } \\
\text { necrotization in follow-up MRI }\end{array}$ & $\begin{array}{l}\text { Pleocytosis and } \\
\text { elevated total } \\
\text { protein levels }\end{array}$ & No information available. & $\begin{array}{l}\text { High-dose steroid } \\
\text { therapy and } \\
\text { immune absorption }\end{array}$ & $\begin{array}{l}\text { Recovered with } \\
\text { sequelae }\end{array}$ \\
\hline 2 & $\begin{array}{l}\text { F/43/ } \\
\text { Germany }\end{array}$ & $\begin{array}{l}\text { Suspicion of DRESS } \\
\text { syndrome with CNS } \\
\text { manifestation }\end{array}$ & $\begin{array}{l}\text { Fever, skin eruption, and } \\
\text { MS exacerbation with } \\
\text { tetraparesis }\end{array}$ & Prominent lesion progression & Pleocytosis & $\begin{array}{l}\text { Inflammatory demyelinating } \\
\text { CNS process and eosinophilic } \\
\text { infiltration }\end{array}$ & $\begin{array}{l}\text { High-dose steroid } \\
\text { therapy, } \\
\text { plasmapheresis, } \\
\text { cyclophosphamide, } \\
\text { and rituximab }\end{array}$ & $\begin{array}{l}\text { Severe } \\
\text { disability } \\
\text { resulting in } \\
\text { foster care }\end{array}$ \\
\hline 3 & $\begin{array}{l}\text { F/30/ } \\
\text { Germany }\end{array}$ & $\begin{array}{l}\text { Inflammatory } \\
\text { demyelinating CNS } \\
\text { process, NMDA } \\
\text { receptor-associated } \\
\text { encephalitis and DRESS } \\
\text { syndrome with CNS } \\
\text { manifestation }\end{array}$ & $\begin{array}{l}\text { Severe MS relapse, fever, } \\
\text { rash, facial edema, } \\
\text { paresthesia, severe hair } \\
\text { loss, memory disturbance, } \\
\text { personality change, and } \\
\text { tonic-clonic seizure }\end{array}$ & $\begin{array}{l}\text { Distinct progression in the size of } \\
\text { preexisting MS lesions and multiple, } \\
\text { partially contrast-enhancing, new lesions }\end{array}$ & $\begin{array}{l}\text { Positive presence } \\
\text { of NMDA } \\
\text { receptor } \\
\text { antibodies }\end{array}$ & $\begin{array}{l}\text { Inflammatory demyelinating } \\
\text { CNS process, signs of } \\
\text { cerebral vasculitis, and } \\
\text { eosinophilic infiltration }\end{array}$ & $\begin{array}{l}\text { High-dose steroid } \\
\text { therapy and } \\
\text { plasmapheresis }\end{array}$ & Partial recovery \\
\hline 4 & $\begin{array}{l}\text { F/33/ } \\
\text { Germany }\end{array}$ & $\begin{array}{l}\text { Suspicion of DRESS } \\
\text { syndrome with CNS } \\
\text { manifestation }\end{array}$ & $\begin{array}{l}\text { MS relapses, fatigue, cough, } \\
\text { fever, joint pain, muscle } \\
\text { tension, nuchal pain, } \\
\text { holocephalic headache, } \\
\text { and nausea }\end{array}$ & $\begin{array}{l}\text { Disseminated contrast-enhancing lesions } \\
\text { with perifocal edema. Signs of cerebellar } \\
\text { swelling. }\end{array}$ & $\begin{array}{l}\text { Pleocytosis and } \\
\text { elevated total } \\
\text { protein and } \\
\text { elevated lactate } \\
\text { levels }\end{array}$ & $\begin{array}{l}\text { Inflammatory demyelinating } \\
\text { CNS process, signs of } \\
\text { cerebral vasculitis, } \\
\text { lymphoplasmacellular } \\
\text { meningoencephalitis, and } \\
\text { eosinophilic infiltration }\end{array}$ & $\begin{array}{l}\text { High-dose steroid } \\
\text { therapy, } \\
\text { plasmapheresis, } \\
\text { and craniectomy } \\
\text { (because of } \\
\text { cerebellar swelling) }\end{array}$ & $\begin{array}{l}\text { Tetrasyndrome } \\
\text { and partial } \\
\text { recovery }\end{array}$ \\
\hline 5 & $\begin{array}{l}\text { F/38/ } \\
\text { Germany }\end{array}$ & $\begin{array}{l}\text { Inflammatory } \\
\text { demyelinating CNS } \\
\text { process }\end{array}$ & $\begin{array}{l}\text { Fever, facial edema, } \\
\text { epileptic seizures, } \\
\text { fulminant MS relapse with } \\
\text { progressive paraparesis, } \\
\text { and vigilance reduction }\end{array}$ & No information available & $\begin{array}{l}\text { No information } \\
\text { available }\end{array}$ & $\begin{array}{l}\text { Inflammatory demyelinating } \\
\text { CNS process }\end{array}$ & $\begin{array}{l}\text { High-dose steroid } \\
\text { therapy and } \\
\text { plasmapheresis }\end{array}$ & $\begin{array}{l}\text { Recovered with } \\
\text { sequelae }\end{array}$ \\
\hline 6 & $\begin{array}{l}\text { F/42/ } \\
\text { United } \\
\text { States } \\
\text { (reported } \\
\text { in Ref. }{ }^{6} \text { ) }\end{array}$ & CNS vasculitis & $\begin{array}{l}\text { Headaches, fever, weight } \\
\text { loss, arthralgia, ataxia, and } \\
\text { gait difficulty }\end{array}$ & $\begin{array}{l}\text { Numerous cerebral T2-weighted lesions } \\
\text { and striking linear contrast enhancement } \\
\text { in the deep medullary veins; diffuse } \\
\text { intramedullary cord abnormalities with } \\
\text { cord swelling, edema, and numerous } \\
\text { petechial foci of contrast-enhancement }\end{array}$ & $\begin{array}{l}\text { Pleocytosis and } \\
\text { elevated total } \\
\text { protein levels }\end{array}$ & $\begin{array}{l}\text { Cerebral vasculitis and no } \\
\text { evidence of demyelination }\end{array}$ & $\begin{array}{l}\text { High-dose steroid } \\
\text { therapy and } \\
\text { cyclophosphamide }\end{array}$ & Partial recovery \\
\hline 7 & $\begin{array}{l}\text { M/32/ } \\
\text { Germany } \\
\text { (case } \\
\text { presented } \\
\text { here) }\end{array}$ & $\begin{array}{l}\text { Steroid-responsive } \\
\text { GFAPa IgG-mediated } \\
\text { encephalitis }\end{array}$ & $\begin{array}{l}\text { Perceptive impairment, } \\
\text { confusion, incoherent } \\
\text { thoughts, delusions, slight } \\
\text { ataxia, and nystagmus }\end{array}$ & $\begin{array}{l}\text { New juxtacortical lesion in the right gyrus } \\
\text { frontalis medius and a new focal gliosis in } \\
\text { the spinal cord at level Th3/4 }\end{array}$ & $\begin{array}{l}\text { Pleocytosis and } \\
\text { elevated total } \\
\text { protein levels and } \\
\text { positive presence } \\
\text { of GFAPa IgG } \\
\text { antibodies }\end{array}$ & No information available. & $\begin{array}{l}\text { High-dose steroid } \\
\text { therapy, } \\
\text { plasmapheresis, } \\
\text { and rituximab }\end{array}$ & Partial recovery \\
\hline
\end{tabular}

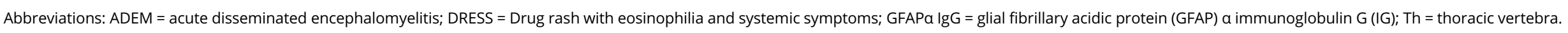




\section{Study funding}

This study has been supported by the German Research Foundation (DFG, CRC-TR-128 to F.Z.).

\section{Disclosure}

F. Luessi served on the advisory board of Roche and received travel funding from Teva and Merck Serono. S. Engel reports no disclosures. A. Spreer received travel funding and speaker honoraria from Deutsche Gesellschaft für Liquoranalytik und Neurochemie and Institut Virion/Serion. S. Bittner received travel funding and/or speaker honoraria from Biogen, Merck Serono, Novartis, Roche, and Sanofi/Genzyme. F. Zipp received travel funding and consultation fees from Teva, Novartis, Merck Serono, Bayer, Biogen, Ono, Genzyme, Sanofi-Aventis, and Octapharma, consulted for DFG and PCORI PRAG-MS; and received research support from Progressive MS Alliance-BRAVEinMS, Teva, Novartis, Merck Serono, and Bayer. Full disclosure form information provided by the authors is available with the full text of this article at Neurology.org/NN.
Received April 16, 2018. Accepted in final form May 31, 2018.

\section{References}

1. Kappos L, Wiendl H, Selmaj K, et al. Daclizumab HYP versus interferon beta-1a in relapsing multiple sclerosis. N Engl J Med 2015;373:1418-1428.

2. Fleischer V, Friedrich M, Rezk A, et al. Treatment response to dimethyl fumarate is characterized by disproportionate CD8+ T cell reduction in MS. Mult Scler 2018;24: 632-641.

3. Fang B, McKeon A, Hinson SR, et al. Autoimmune glial fibrillary acidic protein astrocytopathy: a novel meningoencephalomyelitis. JAMA Neurol 2016;73:1297-1307.

4. Iorio R, Damato V, Evoli A, et al. Clinical and immunological characteristics of the spectrum of GFAP autoimmunity: a case series of 22 patients. J Neurol Neurosurg Psychiatry 2018;89:138-146.

5. Flanagan EP, Hinson SR, Lennon VA, et al. Glial fibrillary acidic protein immunoglobulin $\mathrm{G}$ as biomarker of autoimmune astrocytopathy: analysis of 102 patients. Ann Neurol 2017;81:298-309.

6. Ohayon J, Oh U, Richert N, et al. CNS vasculitis in a patient with MS on daclizumab monotherapy. Neurology 2013;80:453-457.

7. Ratelade J, Zhang H, Saadoun S, Bennett JL, Papadopoulos MC, Verkman AS. Neuromyelitis optica IgG and natural killer cells produce NMO lesions in mice without myelin loss. Acta Neuropathol 2012;123:861-872.

8. Barkhof F, Ciccarelli O. Daclizumab in multiple sclerosis: a high-yield extension study Lancet Neurol 2014;13:443-444.

9. Pfender N, Martin R. Daclizumab (anti-CD25) in multiple sclerosis. Exp Neurol 2014;262:44-51.

10. Cohan S, Kappos L, Holman J, Chen H, Fam S, Parks B. Long-term safety of daclizumab beta in patients with relapsing MS in EXTEND: interim results from treatment up to 6 years. Mult Scler 2017;23:64. 


\section{Neurology \\ Neuroimmunology \& Neuroinflammation}

GFAP $\propto$ IgG-associated encephalitis upon daclizumab treatment of MS

Felix Luessi, Sinah Engel, Annette Spreer, et al.

Neurol Neuroimmunol Neuroinflamm 2018;5;

DOI 10.1212/NXI.0000000000000481

This information is current as of July 13, 2018

\section{Updated Information \& Services}

References

Citations

Subspecialty Collections

Permissions \& Licensing

Reprints including high resolution figures, can be found at:

http://nn.neurology.org/content/5/5/e481.full.html

This article cites 10 articles, 1 of which you can access for free at: http://nn.neurology.org/content/5/5/e481.full.html\#\#ref-list-1

This article has been cited by 3 HighWire-hosted articles: http://nn.neurology.org/content/5/5/e481.full.html\#\#otherarticles

This article, along with others on similar topics, appears in the following collection(s):

Autoimmune diseases

http://nn.neurology.org//cgi/collection/autoimmune_diseases Multiple sclerosis

http://nn.neurology.org//cgi/collection/multiple_sclerosis

Information about reproducing this article in parts (figures,tables) or in its entirety can be found online at:

http://nn.neurology.org/misc/about.xhtml\#permissions

Information about ordering reprints can be found online:

http://nn.neurology.org/misc/addir.xhtml\#reprintsus

Neurol Neuroimmunol Neuroinflamm is an official journal of the American Academy of Neurology.

Published since April 2014, it is an open-access, online-only, continuous publication journal. Copyright

Copyright $\left({ }^{\circ} 2018\right.$ The Author(s). Published by Wolters Kluwer Health, Inc. on behalf of the American

Academy of Neurology.. All rights reserved. Online ISSN: 2332-7812.

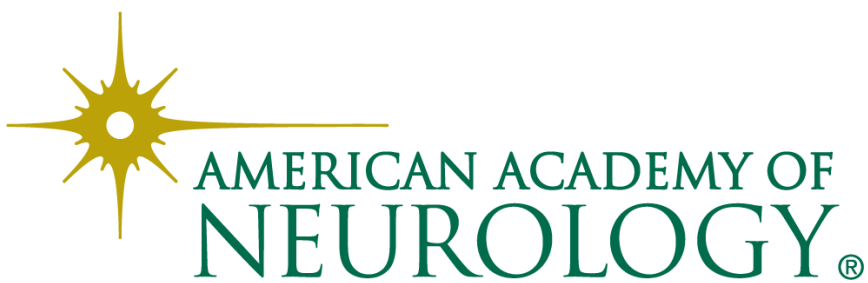

